\title{
Articles
}

\section{Comprehension and Production Practice in Grammar Instruction: Does Their Combined Use Facilitate Second Language Acquisition?}

\author{
Takeo Tanaka \\ Yamanashi University
}

Grammar instruction usually consists of explanation, feedback, and practice. Recent studies (e.g., Dekeyser \& Sokalski, 1996; Ellis, 1993, 1995; VanPatten \& Cadierno, 1993) focus on the relative effectiveness of comprehension and production practice in grammar instruction yet tend to treat the two forms of practice as mutually exclusive. Previous studies on input and output processing in second language acquisition, however, indicate that comprehension and production practice each play unique roles in the development of knowledge, promoting accurate and fluent language use. Suggesting that the two forms of practice can be complementary, this study examines the effects of combining comprehension and production practice in grammar instruction and considers the role of practice in second language acquisition.

第二言語の授業での文法指遒において，一般的に文法説明とともに目標項目 の練習が行われる. 文法指導の練習の区分の一つとして, 理解型の練習と表出 型の練習がある. 最近の研究では，文法指導におけるこの 2 つの練習の効果が 比較検討されてきているが, これらの研究においてこの 2 つの練習の役割は 別々に切り離して捉えられる傾向にある．本研究では，理解型の練習と表出型 の練習を組み合わせた場合，個々に練習を行う場合よりも練習効果が大きくな るとの仮説を立て，心理動詞を目標構造とし日本人短大生を被験者として，練 習効果を測定する実験を行った，その結果，理解型と表出型の練習を組み合わ せた文法指導は，個々に練習を行う文法指導よりも効果的な学習をもたらし， その指導効果が持続することが明らかになった。

tudies on the role of grammar instruction in second language acquisition have generally investigated whether specific grammatical structures can be acquired through formal instruction (e.g., Pica, 1983; White, Spada, Lightbown, \& Ranta, 1991) yet, as some researchers have pointed out (e.g., Ellis, 1997; Spada, 1997), many of these studies have not examined the instructional procedures used. 
Increasingly, however, the focus of research is shifting to investigation of what methods of instruction yield significant effects (e.g., Doughty, 1991; Fotos, 1994).

This article focuses on the role of practice in grammar instruction. It reports on the results of several recent studies (e.g., Salaberry, 1997; VanPatten \& Cadierno, 1993) which compare the relative effectiveness of comprehension-based and production-based grammar instruction, noting that these studies have treated comprehension and production practice as disparate means for learning. However, this paper suggests that the two forms of practice can play complementary roles in promoting the acquisition of grammatical structures and presents an empirical study on the effects of combined practice in grammar learning.

\section{Comprehension Practice Versus Production Practice in Grammar Instruction}

There is general agreement among theorists that, for second language acquisition to take place, learners must receive comprehensible input in the target language (Ellis, 1985; Gass, 1988; Krashen, 1982). In addition, Schmidt (1990) suggests that second language acquisition is facilitated not only by understanding the meaning of the input, but also by noticing specific structures while processing the input. Although these theories recognize the importance of input-based instruction for grammar learning, it has been pointed out that many current textbooks and grammar instruction materials employ only production practice for grammar instruction (Ellis, 1993, 1995; VanPatten \& Cadierno, 1993). Ellis (1993) considers this tendency problematic for several reasons. First, according to Pienemann's learnability hypothesis (Pienemann, 1985) asking learners to produce target structures they are not developmentally ready to produce may hinder their successful acquisition of the forms. Furthermore, requiring learners to produce target structures they find difficult may arouse their anxiety, thus blocking acquisition (Krashen, 1982).

Comprehension practice has therefore been advanced as an alternative to the production practice traditionally utilized in grammar instruction. In comprehension practice learners focus their attention on a target structure while processing input. Such practice does not require the learners' production of the target structure following the grammar explanation. Rather, they read or listen to a text containing specific target structures and indicate their understanding of it. Such comprehension-based instruction is thought to circumvent both the learnability problem and anxiety that might impede acquisition (Ellis, 1993, 1995; 
VanPatten \& Cadierno, 1993).

Several recent studies provide evidence for the advantage of instruction utilizing comprehension practice. For example, VanPatten and Cadierno (1993) compared the effect of comprehension-based instruction with that of production-based instruction for 129 university learners of Spanish. The comprehension-based instruction group was given an explanation of Spanish object clitic pronouns followed by comprehension practice. The production-based instruction group received the same explanation followed by production practice. Both groups received a comprehension test and a production test in pretest and posttest format. The results of the first posttest given immediately after instruction showed that the comprehension-based instruction group gained on both comprehension and production test scores, whereas the production-based instruction group only gained on the production test, not on the comprehension test. The second posttest conducted one month later produced the same results. The authors therefore suggested that comprehension practice in grammar instruction can lead to more effective learning.

Cadierno (1995) and Cheng (1995) conducted similar studies directed at the acquisition of the Spanish past tense and the durative and punctual aspects respectively. Their results confirmed VanPatten and Cadierno's results showing that comprehension-based instruction was more beneficial than production-based instruction. VanPatten and his associates' studies thus indicated that comprehension-based grammar instruction should replace traditional production-based instruction in grammar classrooms (Cadierno, 1995; Ellis, 1993, 1995; VanPatten \& Cadierno, 1993).

Other studies, however, obtained results contrary to those of VanPatten and his associates. Salaberry (1997) replicated VanPatten and Cadierno's 1993 study but failed to show an advantage for instruction using comprehension practice. In order to examine the acquisition of Spanish clitic pronouns by 26 university students, the study administered a written comprehension test, a written production test, and a free-writing narration test. Both the production-based instruction and the comprehension-based instruction groups showed similar improvement on the comprehension test, but neither group showed a gain on the production test or on the free narrative test. Dekeyser and Sokalski's (1996) study, which replicated Dekeyser's (1996) pilot study focusing on the clitic pronouns and the conditional in Spanish, also found no advantage for comprehension-based instruction.

Consequently, although studies have sought to investigate the effects of comprehension and production practice on the acquisition of 
different grammatical structures, it remains unclear which of these two forms of practice is more effective. One problem with the studies discussed above is that they treat comprehension and production practice as mutually exclusive. Speculating that the two forms of practice play different roles in developing learners' grammatical knowledge, it can be suggested that both types of practice are necessary and can play complementary roles in grammar instruction.

\section{The Roles of Practice in Grammar Instruction}

Before a closer examination of the roles that comprehension and production practice can play in the process of second language acquisition, it is necessary to briefly consider the current role of practice in grammar instruction.

\section{Types of Practice}

Practice in grammar instruction can be carried out in two general ways. There is practice that aims to consolidate the learning of grammatical rules, often called controlled practice (Ellis, 1991), and there is practice that requires learners to fully employ the grammar rules in a communicative situation, this called free practice (Ellis, 1991; Littlewood, 1981; Rivers, 1983). Controlled practice focuses on the use of specific grammatical structures to perform tasks whereas free practice is geared primarily to having learners communicate as best they can with the knowledge they currently possess rather than to deliberately use targeted language structures.

The present study focuses on controlled practice, practice which explicitly targets a specific structure. Controlled practice can be divided into three types, mechanical, meaningful and communicative, according to the degree of control the learners have over the response (Paulston, 1971) and the nature of cognitive processes during practice (Dekeyser, 1998; Yamaoka, 1992). Repetition, substitution, or transformation of target structures fall under mechanical practice. In this type of practice the learners can perform a task without linking the structure and its meaning since they do not have to understand what they are saying to complete the task. In contrast, meaningful practice requires the learners to attend to meaning, although the interlocutor already knows the response. In communicative practice the learners must manage content unknown to the interlocutor. For example, in order to communicatively practice the past tense of verbs, students are asked to use target verbs to describe what they did or did not do 
over the weekend (e.g., given the verb "play," the students make sentences such as "I played tennis with my friends on Sunday" or "I did not play tennis on Sunday."). Practice is thus controlled because it focuses on the use of a specific structure but it is also meaningful because it requires the students to use the structure to express meaning. The purpose of this type of practice is to develop the learners' ability to synthesize the parts of language. However, both meaningful and communicative practice require the learners to link a form to its meaning to complete the task and are thought to develop the learners' ability to use a language for real communication (Dekeyser, 1998). In this paper the term "practice" therefore refers to meaningful or communicative controlled practice.

\section{How Practice Promotes Second Language Acquisition}

Arguments have been made regarding the role of grammar instruction in second language acquisition and whether or not "learned" knowledge gained during instruction can become "acquired" knowledge necessary for using a language for communication (Bialystock, 1981; Krashen, 1985; McLaughlin, 1978; Seliger, 1979). Although it is difficult to draw firm conclusions, the evidence available from research suggests that learned knowledge may be acquired if learners are ready to incorporate grammatical rules into their interlanguage systems (Ellis, 1997; Pienemann, 1985). Moreover, it has also been suggested that practice is a means whereby learned knowledge is transformed into acquired knowledge (Bialystock, 1981; McLaughlin, 1987; McLaughlin, Rossman \& McLeod, 1983; Sharwood Smith, 1981). However, it has yet to be clarified precisely how practice functions in the development of acquired knowledge.

In order to obtain some insight into the roles of comprehension and production practice let us consider a mental representation of the learners' knowledge. Bialystock and Sharwood Smith (1985) suggest that second language acquisition can be viewed in terms of control and knowledge. Control refers to how existing knowledge is utilized during actual performance and knowledge refers to how the language system is represented in long-term storage. This concept of control is similar to the concept of language processing proposed by Shiffrin and Schneider (1977) and McLaughlin, et al. (1983). According to their view, learning a language is a progression from limited and controlled processing of information requiring much cognitive effort to automatic processing with little effort in handling a lot of information simulta- 
neously.

It is not controversial that repeated practice facilitates automatization of information processing (Dekeyser, 1996; McLaughlin, et al., 1983). Comprehension practice develops the learners' ability to comprehend the meaning of a spoken or written passage, establishing formmeaning connections of target structures in the input (VanPatten \& Cadierno, 1993; Terrell, 1991), whereas production practice develops the learners' ability to formulate a message and convey it in spoken or written form. Form-meaning connections of target structures are reinforced in producing language and learners gain faster access to the structure (de Bot, 1996; Swain, 1995; Terrell, 1991). Thus both comprehension and production practice function to automatize the receptive and productive language processing. Automatization is believed to reduce the cognitive load imposed on working memory and to facilitate ongoing language comprehension and production (VanPatten, 1987).

Another aspect concerns the development of knowledge. Here second language acquisition is viewed as knowledge construction in terms of quantity and quality. The "quantity" of knowledge refers to how much the learners know about the language system and the "quality" of knowledge refers to how the learners have organized the system in their minds. A substantial body of research indicates that comprehension and production practice may serve independent but significant roles in the construction of the learners' knowledge system. In comprehension practice, the learners notice the form and function of a specific structure (see Schmidt, 1990) and compare the noticed structure with their existing knowledge (Faerch \& Kasper, 1986; Schmidt \& Frota, 1986; Skehan, 1998). It is thought that in doing so, the learners integrate the structure into their own interlanguage systems (McLaughlin, 1990; Skehan, 1998). During production practice, the learners perceive a gap in what they want to say and what they are able to say, resulting in increased awareness of those structures so that they are noticed in subsequent input (de Bot, 1996; Swain, 1993, 1995). Through production practice, learners can also test out their knowledge of the target language when they receive feedback from interlocutors. During this process they may also restructure their existing interlanguage systems (de Bot, 1996; Swain, 1985, 1993, 1995). Furthermore, it has been suggested that the learners' own output may serve as additional input (Sharwood Smith, 1981).

The automatization of information processing can thus be achieved through practice. Gradually learners gain the capacity to deal with new information, thereby increasing their quantity and quality of knowl- 
edge. If second language acquisition involves the development of these two mental mechanisms (i.e., the automatization of information processing and the construction of knowledge), then it appears that both comprehension practice and production practice are important in grammar learning and each has a unique role to play.

\section{The Present Study}

If it is true that each form of practice serves a unique role, then it can be suggested that comprehension and production practice complement each other in the development of learners' interlanguage systems. The effects of comprehension practice can be reinforced by production practice and vice versa. It should be noted, however, that there have been few attempts to confirm the effectiveness of combining the two forms of practice for grammar learning (Ellis, 1998). What effects, if any, are gained? The question is intriguing and important.

In a preliminary study Tanaka (1999) investigated whether combining the two forms of practice would yield better results in a study of relative clause sentences in both written and spoken modes. Relative clause sentences are characterized by a complex syntactic structure that includes the relationship between the relative clause and its matrix sentence (O'Grady, 1997). The subjects of the experiment were Japanese EFL (English as a foreign language) students from a high school and a junior college. They were divided into three groups according to the type of practice they received after an explanation of the target grammar structure. One group was given comprehension practice, another group was given production practice, and the third group was given a combination of comprehension and production practice. The results of this preliminary study indicated that combining comprehension and production practice led to more effective grammar learning and that the effect was sustained over time for both written and spoken modes of practice.

In the current study a less complex syntactic structure was targeted to see if similar resuits would be obtained.

\section{Research Questions}

The present study follows Tanaka's earlier study (1999) in order to further investigate the effects of combined production and comprehension practice. As before, two research questions were considered:

(1) Does a combination of comprehension practice and production practice bring about better learning than their separate use by a sample of Japanese junior college EFL learners?

(2) If so, are these results maintained over time? 


\section{Method}

\section{Subjects}

The initial 130 subjects in this study were drawn from four intact classes taught by the researcher in the English language department of a private junior college in Osaka, Japan. The subjects were Japanese first and second year English majors enrolled in weekly ninety-minute classes that focused on developing their English communication skills. They were mostly female (male to female: 10:120) ranging in age from 18 to 20 . Since the students had had to pass the school's entrance examination, including an English proficiency test, it is suggested that they were quite homogeneous in terms of their English proficiency. The mean TOEIC score for the school was 319.4 points. The number of subjects was reduced to 65 by omitting those who scored $90 \%$ and above on the pretest and those who did not take one of the treatments or tests.

The subjects were divided into four groups according to the type of practice given (see Figure 3): The first group (Prod-Group: $n=15$ ) was given production practice only. The second group (Comp-Group: $n=$ 22) was given comprehension practice only. The third group (MixedGroup: $n=15$ ) was given both comprehension and production practice. The fourth group (Control-Group: $n=13$ ) was not given any form of practice.

A listening test developed by the researcher (see Appendix 1) was administered to compare the general English aural proficiency levels of the four groups prior to instruction. The listening test required the subjects to answer 12 tape-recorded questions. The results of the test are shown in Table 1 . The Levene homogeneity of variance test revealed that there was equal variance among the listening test scores of the four groups (the Levene statistic is $.071, p=.98$ ), thus the four groups were considered equivalent in their initial English proficiency.

Table 1: Descriptive Statistics for the Listening Test

\begin{tabular}{lllll}
\hline & $N$ & Means & SD & Range \\
\hline Comp-Group & 22 & 5.59 & 1.76 & $3-9$ \\
Prod-Group & 15 & 5.93 & 1.98 & $3-9$ \\
Mixed-Group & 15 & 5.87 & 2.03 & $2-9$ \\
Control-Group & 13 & 6.69 & 1.97 & $2-9$ \\
\hline Total & 65 & 5.95 & 1.92 & $2-9$ \\
\hline
\end{tabular}

Note: Maximum score $=12$ 


\section{Target Structure}

Psychological verbs in English indicate an affective state. Examples of this type of verb include like, bore, and worry. It has been suggested that such verbs constitute psychological predicate constructions which are problematic for English language learners (Burt, 1975). Psychological verbs have been divided into two types according to the nature of their syntactic structure (Belletti \& Rizzi, 1988). As shown in Figure 1(1), the first type of verb is referred to as the "Fear type." Here the subject of the sentence, people, functions as the experiencer of the psychological verb like, and its object, dogs, functions as the theme of the sentence. The second type of psychological verb, shown in Figure 1-(2), is referred to as the "Worry type." Here the subject of the sentence, people, functions as the theme and the object, dogs, functions as the experiencer of the verb disgust.

Figure 1: Types of Psychological Verbs
(1) The Fear Type
(2) The Worry Type
People like dogs.
People disgust dogs.
[experiencer theme]
[theme experiencer]

The word order of the Fear type is considered less marked in English (e.g., like, enjoy, want), while that of the Worry type (e.g., disgust, depress, frighten) is considered more marked and problematic (see Ellis, 1997). Learners are likely to overgeneralize the Fear-type pattern, thus mistaking Worry-type sentences as Fear-type sentences. For example, the meaning of the sentence People disgust dogs is often mistaken as Dogs make people disgusted by learners of English.

In order to comprehend or produce psychological verbs correctly, learners need to understand that psychological verbs are divided into two types according to the word order of the sentence and then must correctly identify the verb type. An unpublished pilot study conducted with different subjects $(n=68)$ suggested that it is difficult for Japanese EFL learners to comprehend sentences that include psychological verbs so it was determined psychological verbs would be an appropriate target structure for measuring the effectiveness of practice.

\section{Procedures and Materials}

The experiment included a pretest followed a week later by grammar instruction consisting of explanation and the different practice regimes. In order to examine the effectiveness of practice, two posttests were 
given after the instruction. Posttest 1 was conducted a week after the instruction and posttest 2 one month after the instruction.

\section{Pretest/Posttests}

Natural communication requires the learners' psycholinguistic ability to comprehend and produce the target language accurately and fluently. In order to measure this ability, it is important to employ meaning-focused tasks that demand the subjects' full attention to the message while processing the language accurately in a limited time (Ellis, 1997).

The subjects received both aural comprehension tests and verbal production tests. Each test consisted of ten questions including four Fear-type verbs and six Worry-type verbs for a maximum possible score of ten (see Figure 2 for the test sentences and Appendices 2 and 3 for the drawings corresponding to these sentences). The $4-6$ split in test items was made because an earlier unpublished pilot study indicated that Japanese EFL students had more difficulty in identifying the experiencer of the Worry-type sentences than the Fear-type. Thus, the tests were designed to be a little more challenging to the subjects. Figure 2 shows the test sentences. The underlined numbers indicate Worry-type sentences.

Figure 2: Test Sentences

$\begin{array}{ll}\text { Comprehension Test } & \text { Production Test } \\ \text { 1. Nancy respects Mike. } & \text { 1. Tom bothers Mary. } \\ \text { 2. Mike hates Bob. } & \text { 2. Tom envies Kate. } \\ \text { 3. Mark surprises Kathy. } & \text { 3. Kathy worries David. } \\ \text { 4. David embarrasses Jane. } & \text { 4. Jane excites Ken. } \\ \text { 5. Janet doubts Brian. } & \text { 5. Brian suspects Kate. } \\ \text { 6. Brian scares Akiko. } & \text { 6. Ken frightens Janet. } \\ \text { Z Mike interests Kate. } & \text { Z Kate irritates John. } \\ \text { 8. Mary likes Ken. } & \text { 8. Ken loves Janet. } \\ \text { 2. John pleases Emi. } & \text { 9. Tom misses Kate. } \\ \text { 10. Bob disappoints Mary. } & \text { 10. Jane disgusts David. }\end{array}$

For the aural comprehension tests, the subjects listened to tape-recorded sentences and demonstrated their comprehension of each sentence by selecting one of four drawings that best corresponded to the sentence (shown in Appendix 2). Each question took about 15 seconds. The production tests required the subjects to verbally describe a 
drawing using terms from the list of English words supplied (shown in Appendix 3). Their utterances were recorded on tape and six seconds were allowed for each recording. This time limit was determined by a preliminary investigation of the instrument using four native speakers of English who took the comprehension and production tests. The mean time spent for each test item was calculated and the native English speakers were also asked to confirm the authenticity of the sentences and drawings. Another unpublished pilot study was conducted using five students who were not included in the current study in order to examine the difficulty of the comprehension and production tests and the appropriateness of the time limits. As a result some test items were modified.

Each of the pretests and posttests was presented using the same vocabulary and drawings but these were arranged in a different order. Cronbach's alpha statistics calculated for the comprehension and production pretests were .69 and .66 respectively. Despite the small number of subjects $(n=65)$ and test items (10 for each test) in this study, it was felt that the tests were reliable.

\section{Figure 3: Procedure of the Present Study}

\begin{tabular}{|c|c|c|c|}
\hline Prod-Group & Comp-Group & Mixed-Group & Control-Group \\
\hline \multicolumn{4}{|l|}{1 week before instruction } \\
\hline \multicolumn{4}{|c|}{ Pretest (Comprehension Test + Production Test) } \\
\hline Grammar Explanation & Grammar Explanation & Grammar Explanation & Grammar Explanation \\
\hline Production Practice & Comprehension Practice & Comprehension Practice & \\
\hline Production Practice & Comprehension Practice & Production Practice & \\
\hline \multicolumn{4}{|l|}{ I week after instruction } \\
\hline & \multicolumn{3}{|c|}{ Posttest 1 (Comprehension Test + Production Test) } \\
\hline \multicolumn{4}{|l|}{ I month after instruction } \\
\hline & Posttest 2 (Comprehen & n Test + Production Test) & \\
\hline
\end{tabular}




\section{Grammar Instruction}

The three experimental groups (Prod-Group, Comp-Group, and MixedGroup) received the same grammar instruction consisting of an explanation of the target structure. This was followed by practice. However, the control group received the explanation only. The grammar instruction consisted of the following activities. First the students were given handouts explaining the two types of the psychological verb (i.e., the Fear-type and the Worry-type). The teacher/researcher explained that the experiencer precedes the verb in the Fear-type sentence (e.g., People like dogs). Then students read the list of the Fear-type verbs (doubt, love, respect, miss, envy, hate, suspect, like), checking that they understood their meanings. Next the teacher explained that the experiencer followed the verb in the Worry-type sentence (e.g., People disgust dogs), and the students read the list of these verbs (embarrass, scare, bother, please, frighten, surprise, interest, disappoint, excite, disgust, worry) again checking their meanings. After the grammar explanation, the three treatment groups were given practice consisting of 40 questions using both types of psychological verbs. This practice was identical in format to the pretest and posttests sentences given in Figure 2 (also see Appendices 2 and 3 ).

There were two types of practice: comprehension practice and production practice. The members of the Comp-Group were given comprehension practice only. This consisted of listening to 40 audio-taped questions (see Appendices 2 and 3), each of which included a psychological verb. The subjects had to demonstrate their comprehension by selecting one of four drawings best corresponding to the recorded sentence. The members of the Prod-Group were given production practice only. This consisted of 40 drawings which the subjects were required to describe using the vocabulary from the supplied English words. The subjects of the Mixed-Group were given 20 questions from the comprehension practice items and 20 questions from the production practice items. The three groups thus received the same amount of practice, although the Mixed-Group received only half the production practice of the Prod-Group and half of the comprehension practice of the Comp-Group. After each question was completed the correct answers and brief explanations were given to the subjects.

\section{Hypotheses}

As in Tanaka's previous study (1999), two hypotheses were proposed: Hypothesis 1: The Mixed-Group, which was given only half the amount of comprehension practice as the Comp-Group, 
will show gains in the comprehension test scores of posttest 1 equal to or better than Comp-Group, and the Mixed-Group's gains will be sustained in posttest 2 .

Hypothesis 2: The Mixed-Group, which was given only half the amount of production practice as the Prod-Group, will show gains in the production test scores of posttest 1 equal to or better than Prod-Group, and the Mixed-Group's gains will be sustained in posttest 2 .

\section{Statistical Analyses}

The statistical analyses for this study were performed with a commercially available statistical package (SPSS 10.0 for Windows, 1999). Since testing the homogeneity of variances of the data with the Levene test revealed that the groups being analyzed did not have equal variances, the test scores were then submitted to the Kruskal-Wallis test and the Friedman test. In all cases, there were two variables. One was the group type (four levels: Comp-Group, Prod-Group, Mixed-Group, and Control-Group) in which mean scores being compared were all independent. The other variable was the test type (three levels: pretest, posttest 1 , and posttest 2 ) in which the mean scores were all dependent. In order to examine the two hypotheses above, the scores on the comprehension tests were analyzed using three Kruskal-Wallis tests and four Friedman tests. The Kruskal-Wallis tests were used to test the null hypothesis that there would be no significant differences among the mean scores of the four groups. The Friedman tests were used to test the null hypotheses that there were no significant differences among the mean scores of the three tests. Bonferroni tests were used for post hoc testing. Likewise, the scores on the production tests were subjected to three Kruskal-Wallis tests, four Friedman tests, and then the Bonferroni post hoc test. The significance level was set at .05 .

\section{Results}

The mean scores and the standard deviations for both comprehension and production tests are presented in Table 2 . The results of the comprehension tests and production tests are shown below in Figures 4 and 5 respectively. Kruskal-Wallis tests were performed on the comprehension test scores of pretests and posttests 1 and 2 in order to determine whether there were any statistically significant differences among the means of the four groups. There was no significant difference among the four groups' means on the pretest $\left(\chi^{2}=2.29, d f=3, p\right.$ $>.05$ ), but there were significant differences among means for both 
posttests 1 and 2 (respectively, $\chi^{2}=11.65, d f=3, p<.01 ; \chi^{2}=10.31, d f=$ $3, p<.05$ ). Bonferroni post hoc tests (the significance level was set at .0125) revealed that for posttest 1 significant differences were detected for the pairs of Control-Group vs. Prod-Group and Control-Group vs. Comp-Group. For posttest 2, significant differences were reported for the pairs of Control-Group vs. Prod-Group and Control-Group vs. CompGroup.

Friedman tests were performed on the comprehension test scores of the four groups in order to determine whether there were any statistically significant differences among the means in the three tests. There were significant differences among the three tests' mean scores for Prod-Group, Comp-Group, and Mixed-Group (respectively, $\chi^{2}=$ 15.75, $d f=2, p<.01 ; \chi^{2}=26.84, d f=2, p<.01 ; \chi^{2}=12.04, d f=2, p<.01$ ), but no significant difference for Control-Group $\left(\chi^{2}=1.91, d f=2, p>\right.$ .05 ). Bonferroni post hoc tests (the significance level was set at .016) revealed that, for the Prod-Group, significant differences in the means were reported for pretest vs. posttest 1 and pretest vs. posttest 2 . For the Comp-Group, there were significant differences in the means for pretest vs. posttest 1 and pretest vs. posttest 2. For the Mixed-Group, there were significant differences in the means for pretest vs. posttest 1 and pretest vs. posttest 2 .

Table 2: Means and SD for both

Comprehension and Production Tests

\begin{tabular}{|c|c|c|c|c|c|c|c|c|}
\hline & \multicolumn{2}{|c|}{$\begin{array}{r}\text { Prod-Group } \\
(N=15)\end{array}$} & \multicolumn{2}{|c|}{$\begin{array}{c}\text { Comp-Group } \\
(N=22)\end{array}$} & \multicolumn{2}{|c|}{$\begin{array}{c}\text { Mixed-Group } \\
\left(N^{*}=15\right)\end{array}$} & \multicolumn{2}{|c|}{$\begin{array}{c}\text { Control-Group } \\
(N=13)\end{array}$} \\
\hline & $M$ & $(S D)$ & $M$ & (SD) & $M$ & (SD) & $M$ & $(S D)$ \\
\hline \multicolumn{9}{|l|}{ Comprehension Test } \\
\hline Pretest & 6.00 & (1.41) & 5.59 & $(1.22)$ & 5.33 & (1.35) & 6.08 & (1.38) \\
\hline Posttest 1 & 7.83 & $(1.10)$ & 8.41 & $(1.40)$ & 7.73 & $(2.02)$ & 6.46 & (1.39) \\
\hline Posttest 2 & 8.08 & (1.16) & 8.36 & $(1.26)$ & 7.53 & $(2.10)$ & 6.54 & (1.76) \\
\hline \multicolumn{9}{|l|}{ Production Test } \\
\hline Pretest & 5.33 & $(0.90)$ & 4.59 & (1.37) & 5.60 & $(1.68)$ & 5.38 & (1.12) \\
\hline Posttest 1 & 8.00 & $(1.31)$ & 6.23 & $(2.07)$ & 7.73 & $(1.39)$ & 6.38 & (1.39) \\
\hline Posttest 2 & 7.79 & $(1.57)$ & 6.73 & $(1.80)$ & 8.27 & $(1.10)$ & 4.69 & (1.18) \\
\hline
\end{tabular}

\section{Comprehension Test}

As Figure 4 illustrates, both the Comp-Group and Mixed-Group achieved significant gains on posttest 1 and both groups maintained their scores on posttest 2 . The Prod-Group also obtained a significant gain and sustained the gain over time. In contrast, the Control-Group made no gains on posttests 1 and 2. Hypothesis 1 suggested that the Mixed-Group, which was given only half the amount of comprehension practice of 
the Comp-Group, should show significant gains on the comprehension test scores of posttest 1 equal to or better than the Comp-Group, and that these gains would be sustained in posttest 2 . The results show no significant differences between the comprehension test scores of the Mixed-Group and the Comp-Group for either posttest 1 or 2 . Some difference between the comprehension test scores of the two groups existed, as shown in Table 2 (8.41 vs. 7.73 for posttest $1 ; 8.36$ vs. 7.53 for posttest 2), but the similarity of the two groups' scores is meaningful when the small number of subjects in this study is considered (the Comp-Group had 22 subjects and the Mixed-Group had 15 subjects). Thus it can be suggested that the Mixed-Group subjects showed the same type of gains on the comprehension test as the Comp-Group subjects and this positive result was maintained over time. Therefore $\mathrm{Hy}$ pothesis 1 is supported.

\section{Production Test}

Figure 5 illustrates the results of the production test. A Kruskal-Wallis test was conducted on the production test scores of pretest and posttests 1 and 2 respectively in order to determine whether there were any statistically significant differences among the means of the four groups. There was no significant difference among the four groups' means on the pretest $\left(\chi^{2}=6.12, d f=3, p>.05\right)$, but there were significant differences among the four groups' means on both posttests 1 and 2 (respectively, $\chi^{2}=12.12, d f=3, p<.01 ; \chi^{2}=25.87, d f=3, p<.01$ ). Bonferroni post hoc tests (the significance level was set at .0125) revealed that for posttest 1 significant differences in the means were detected for the pairs of Control-Group vs. Prod-Group and for CompGroup vs. Prod-Group. For posttest 2 significant differences in the means were reported for the pairs of Control-Group vs. Prod-Group, Control-Group vs. Comp-Group, Control-Group vs. Mixed-Group, and Comp-Group vs. Mixed-Group.

Friedman tests were conducted on the production test scores of the four groups in order to determine whether there were any statistically significant differences in the means among the three tests. There were significant differences among the three tests' mean scores for the Control-Group, the Prod-Group, the Comp-Group, and the Mixed-Group (respectively, $\chi^{2}=8.19, d f=2, p<.05 ; \chi^{2}=19.0, d f=2, p<.01 ; \chi^{2}=15.27$, $d f=2, p<.01 ; \chi^{2}=14.28, d f=2, p<.01$ ). Bonferroni posthoc tests (the significance level was set at .016) revealed that for the Control-Group, significant differences in the means were reported for posttest 1 vs. posttest 2. For the Prod-Group, significant differences were found 
among pretest vs. posttest 1 and pretest vs. posttest 2 . For the CompGroup, significant differences in the means were found for pretest vs. posttest 1 and pretest vs. posttest 2 . And for the Mixed-Group, significant differences were found for pretest vs. posttest 1 and pretest vs. posttest 2 .

Thus the Prod-Group and Mixed-Group made significant gains on posttest 1 and maintained these gains on posttest 2, whereas the Control-Group did not make significant gains on either posttest. The CompGroup made a significant gain on posttests 1 and 2, but did not improve to the same degree as the Prod-Group or the Mixed-Group. Hypothesis 2 predicts that the Mixed Group, which was given half the amount of production practice as the Prod-Group, will show significant production gains on posttest 1 equal to or better than the ProdGroup, and that these gains will be sustained on posttest 2. In fact, the results of the study showed no significant difference between the Mixed-Group and the Prod-Group production test scores in either posttest 1 or 2 . Thus, the Mixed-Group subjects' production improved to the same degree as that of subjects in the Prod-Group and the gain was sustained over time. Therefore, Hypothesis 2 is also confirmed.

Figure 4: Comprehension Pre/Post Test Scores

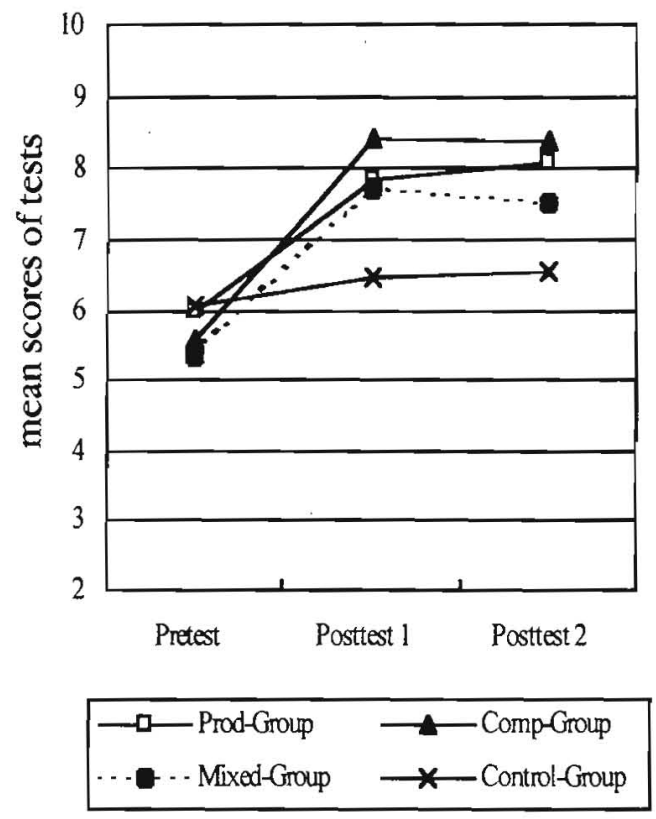


Figure 5: Production Pre/Post Test Scores



Discussion

\section{Positive Effects for Combining Practice Types}

The Mixed-Group test scores for both comprehension and production tasks showed gains equal to those of the Comp-Group and the ProdGroup and the practice effects lasted over time in spite of the fact that the Mixed-Group spent only half the amount of the time their counterparts did on each type of practice. One interpretation for this result is that since the Mixed-Group learners experienced both comprehension and production practice, they had an opportunity to integrate the form and function of the structure into their knowledge in different contexts. Comprehension practice required the learners to listen to a sentence containing a psychological verb, identify the verb type and the verb's experiencer, then select a drawing depicting the sentence within 
a given time (see Appendix 2). In contrast, production practice asked the learners to recognize the meaning of a drawing, identify the verb type, decide upon the correct word order, and verbally describe a drawing using the given words, including psychological verbs (see Appendix 3). It can be suggested that the grammar instruction on psychological verbs was reinforced through both listening to and vocalizing the structure. It thus appears that the Mixed-Group's comprehension and production practice complemented each other to promote learning of the structure. Meanwhile, the Prod-Group and Comp-Group learners, with only one type of practice, did not show better results even though they spent twice as much time on their particular form of practice as the Mixed-Group learners.

\section{Skill-Specific Improvement}

It was also found that the practice effect was skill specific in the sense that the subjects given only comprehension practice improved more on the comprehension tests than the subjects given only production practice and vice versa. This suggests that developing the skill necessary to perform one kind of practice does not guarantee the ability to perform a different kind of practice. Unexpectedly, however, the ProdGroup showed a significant improvement in the comprehension test equal to that of the Comp-Group and Mixed-Group (see Figure 4). This may be due to the fact that production practice was given with the help of words accompanying the drawing (Appendix 3). As explained previously, in an earlier pilot study the subjects had great difficulty producing a verbal description without being provided with words; thus words were included in this study. It can be inferred that the provision of vocabulary items promoted a firmer association of meaning and structure during production practice and thus resulted in significant gains for the Prod-Group on the comprehension test. If this is the case, the current study supports Dekeyser's (1996) and Dekeyser and Sokalski's (1996) findings which indicate that the ability gained from practice may be skill-specific. At the same time, this result contradicts VanPatten and his associates' results suggesting that grammar instruction utilizing production practice does not contribute significantly to comprehension ability. It has been pointed out that VanPatten and his associates' studies require replication using a more controlled experimental design since the subjects performing comprehension practice received more grammar explanation of a qualitatively different nature than those performing production practice (Ellis, 1997; Dekeyser \& Sokalski, 1996; Salaberry, 1997). 
In contrast, the current study was conducted using an identical grammatical explanation for all groups, enabling a more accurate comparison of the effects of comprehension and production practice. The present results confirm that comprehension practice develops comprehension skills and production practice develops production skills. In short, each practice plays a unique role in grammar learning.

It must be acknowledged, however, that this study has important limitations. One is its generalizability. Due to the limited sample size the findings are only true for the students who participated in the current study. Since the current study investigated practice effects for Japanese junior college EFL students, further studies should examine practice effects for younger students: junior high school EFL students, for example. Another limitation is the nature of the target structure. The current study focused on a specific grammatical structure, psychological verbs. This structure includes syntactic features, so configuring the order of words and phrases is crucial to comprehending or producing a sentence. Thus the present results may be limited to the acquisition of grammatical structures with this kind of syntactic feature. Further investigations using diverse structures are necessary.

\section{Conclusion}

As mentioned, other researchers (de Bot, 1996; Dekeyser, 1996; McLaughlin, et al., 1983; Swain, 1995; Terrell, 1991) have suggested that practice in grammar instruction plays a significant role in promoting the automatization of learned grammatical information and the construction of grammar knowledge. Comprehension practice can help learners to notice a target structure, compare it with their existing knowledge, and integrate it into that knowledge. Production practice can also help learners notice the target structure while reconfirming its use and providing additional input via the learners' own output. Thus, the two forms of practice can interact in a synergistic relationship, each shaping and being shaped by the other.

In EFL classroom situations such as those in Japan, creating optimal learning conditions becomes an important issue. The key lies in teachers fully understanding the relationship between practice and second language acquisition. Most current textbooks and materials, however, seem to have been developed without a full understanding of recent findings in second language acquisition. Therefore they lack a balance of practice activities (see Ellis, 1995). Decio (1996) examined grammar practice as presented in ESL/EFL textbooks from 1960 to 1996 , pointing out that it was not contemporary with proposed language 
instruction approaches and suggesting that there has been little advancement in grammar practice strategies provided to the classroom practitioner. As mentioned, past studies of grammar learning (e.g., Ellis, 1995; VanPatten \& Cadierno, 1993) tended to treat comprehension and production practice as playing conflicting roles. However, the present study suggests that combining practice types may promote better learning than their use separately. The results of this and the previous study (Tanaka, 1999) support the claim that combining comprehension and production practice can increase not only immediate comprehension and production abilities, but also may promote durability. Although limited, these results also support Dekeyser's suggestion (Dekeyser, 1996; Dekeyser \& Sokalski, 1996) that practice effects may be skill specific in the sense that learners who practice a target structure through comprehension practice and subsequently take a comprehension test will outperform those who practice the same structure through production practice, and vice versa.

Therefore it is suggested that design and organization of practice activities should incorporate both types of practice. Combining practice can provide a stepping stone to success in second language acquisition.

\section{Acknowledgements}

Special thanks are due to Professor Hiroyoshi Jiju, Hyogo University of Teacher Education, for his helpful comments and valuable suggestions. I would also like to thank Mr. Mark Taylor for reading the entire text in its original form and making a number of insightful suggestions, as well as the two anonymous JALT Journal reviewers for their useful comments.

Takeo Tanaka is an instructor in the Faculty of Education and Human Sciences at Yamanashi University. His current research interests include grammar practice, noticing, input and output processing, and classroom second language acquisition.

\section{References}

Bialystock, E. (1981). The role of linguistic knowledge in second language use. Studies in Second Language Acquisition, 4, 31-45.

Bialystock, E., \& Sharwood Smith, M. (1985). Interlanguage is not a state of mind: An evaluation of the construct for second language acquisition. Applied Linguistics, 6, 101-117.

Burt, M. (1975). Error analysis in the adult EFL classroom. TESOL Quarterly, 9, 53-63. 
Cadierno, T. (1995). Formal instruction from a processing perspective: An investigation into the Spanish past tense. Modern Language Journal, 79, 179193.

Cheng, A. (1995). Grammar instruction and input processing: The acquisition of Spanish 'SER' and 'ESTAR.' Unpublished doctoral dissertation, University of Illinois at Urbana-Champaign. (UMI, No. 9543553).

de Bot, K. (1996). The psycholinguistics of the output hypothesis. Language Learning, 46, 529-555.

Decio, G. A. (1996). Assessment of the evolution of grammar practice in ESL/ EFL textbooks from 1960 until 1996. Unpublished doctoral dissertation, Purdue University, Indiana. (UMI, No. 9713504).

Dekeyser, R. (1996). Exploring automatization processes. TESOL Quarterly, 30, 349-357.

Dekeyser, R. (1998). Beyond focus on form: Cognitive perspectives on learning and practicing second language grammar. In C. Doughty \& J. Williams (Eds.), Focus on form in classroom second language acquisition (pp. 42-63). Cambridge: Cambridge University Press.

Dekeyser, R., \& Sokalski, K. (1996). The differential role of comprehension and production practice. Language Learning, 46, 613-642.

Doughty, C. (1991). Second language instruction does make a difference: Evidence from an empirical study on SL relativization. Studies in Second Language Acquisition, 31, 431-469.

Ellis, R. (1985). Understanding second language acquisition. Oxford: Oxford University Press.

Ellis, R. (1991). Second language acquisition and language pedagogy. Clevedon: Multilingual Matters.

Ellis, R. (1993). Interpretation-based grammar teaching. System, 21, 69-78.

Ellis, R. (1995). Interpretation tasks for grammar teaching. TESOL Quarterly, $29,87-105$.

Ellis, R. (1997). SLA research and language teaching. Oxford: Oxford University Press.

Ellis, R. (1998). Teaching and research: Options in grammar teaching. TESOL Quarterly, 32, 39-60.

Faerch, C., \& Kasper, G. (1986). The role of comprehension in second language learning. Applied Linguistics, 7, 257-274.

Fotos, S. (1994). Integrating grammar instruction and communicative language use through grammar consciousness-raising tasks. TESOL Quarterly, 28, 323346.

Gass, S. (1988). Integrating research areas: A framework for second language acquisition. Applied Linguistics, 9, 198-217.

Krashen, S. (1982). Principles and practice in second language acquisition. Oxford: Pergamon. 


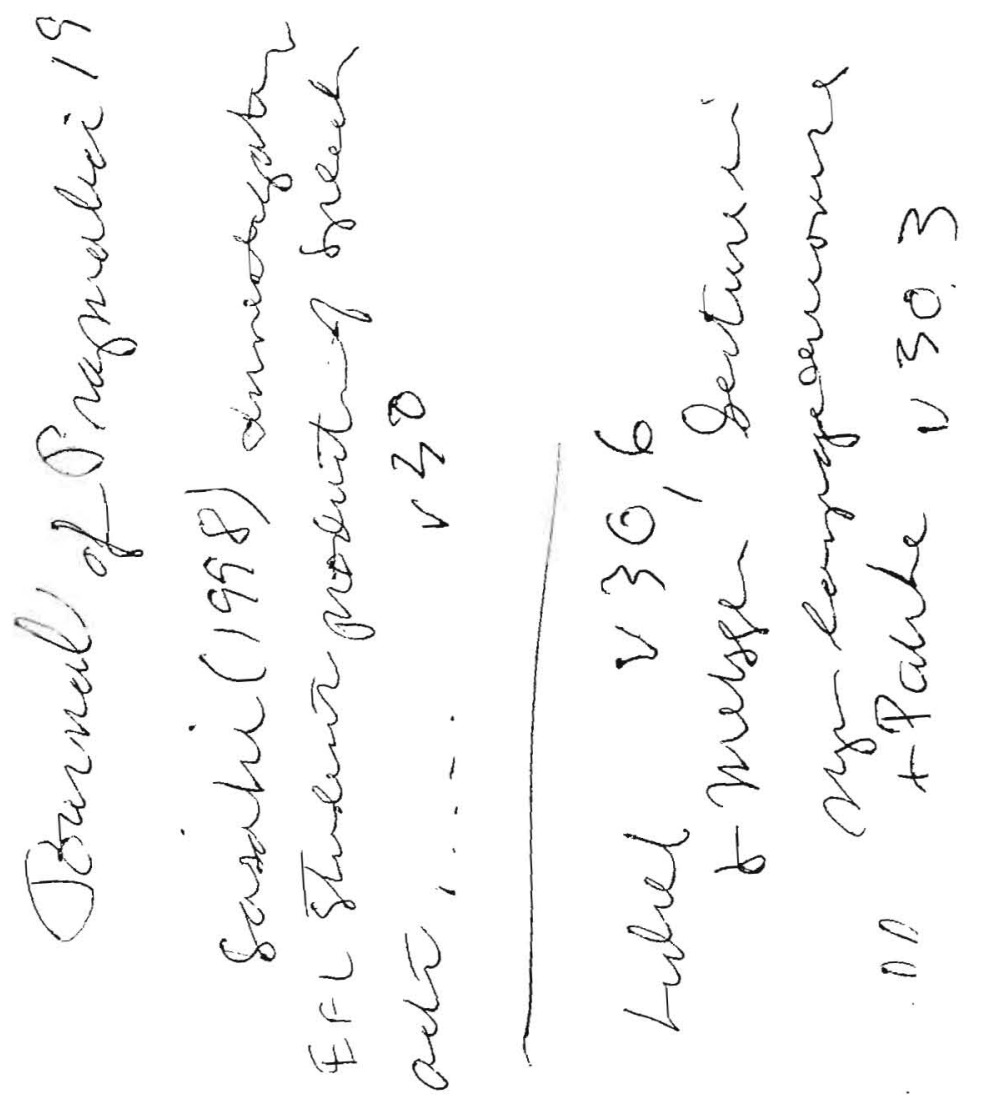




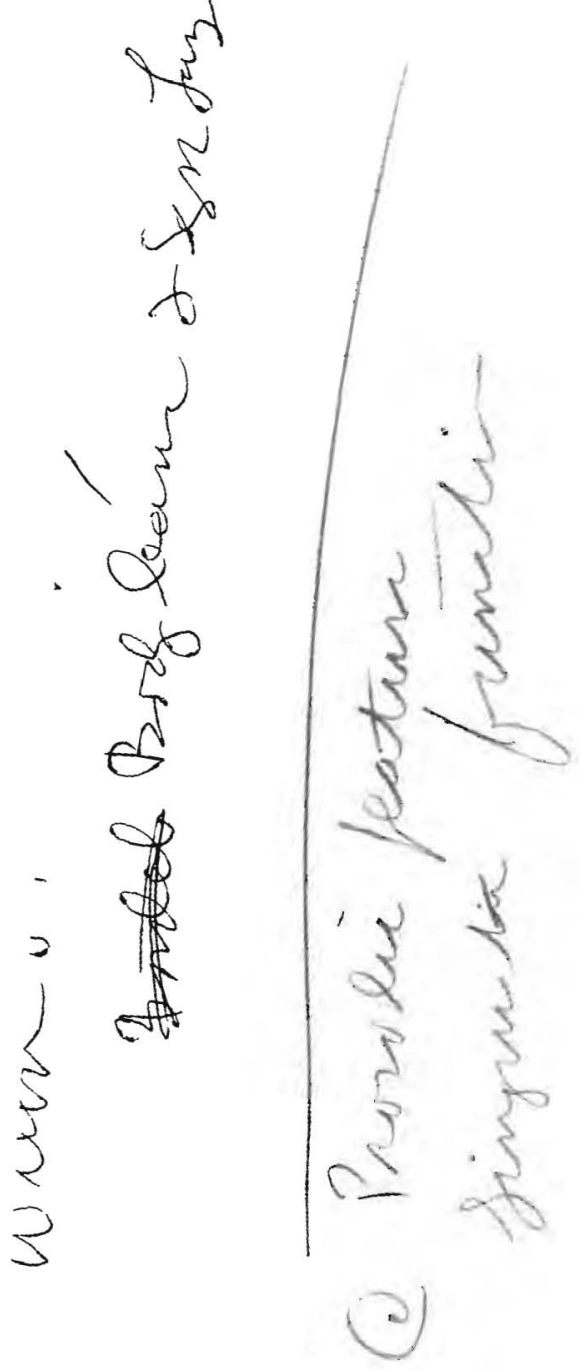


Krashen, S. (1985). The input hypothesis. London: Longman.

Littlewood, W. (1981). Communicative language teaching: An introduction. Cambridge: Cambridge University Press.

McLaughlin, B. (1978). The monitor model: Some methodological considerations. Language Learning, 28, 309-332.

McLaughlin, B. (1987). Theories of second-language learning. London: Edward Arnold.

McLaughlin, B. (1990). Restructuring. Applied Linguistics, 11, 113-128.

McLaughlin, B., Rossman, T., \& McLeod, B. (1983). Second language learning: An information-processing perspective. Language Learning, 33, 135-158.

O'Grady, W. (1997). Syntactic development. Chicago: The University of Chicago Press.

Paulston, C. B. (1971). The sequencing of structural pattern drills. TESOL Quarterly, 5, 197-208.

Pica, T. (1983). Adult acquisition of English as a second language under different conditions of exposure. Language Learning, 33, 465-497.

Pienemann, M. (1985). Learnability and syllabus construction. In K. Hyltenstam \& M. Pienemann (Eds.), Modeling and assessing second language acquisition (pp. 23-75). Clevedon, North Somerset: Multilingual Matters.

Rivers, W. M. (1983). Communicating naturally in a second language: Theory and practice in language teaching. Cambridge: Cambridge University Press.

Salaberry, M. (1997). The role of input and output practice in second language acquisition. Canadian Modern Language Review, 53, 422-451.

Schmidt, R. (1990). The role of consciousness in second language learning. Applied Linguistics, 11, 129-158.

Schmidt, R., \& Frota, S. (1986). Developing basic conversational ability in a second language: A case study of an adult learner of Portuguese. In R. Day (Ed.), Talking to learn: Conversation in second language acquisition (pp. 237-326). Rowley, MA: Newbury House.

Seliger, H. (1979). On the nature and function of language rules in language teaching. TESOL Quarterly, 13, 359-369.

Sharwood Smith, M. (1981). Consciousness-raising and the second-language learner. Applied Linguistics, 2, 159-168.

Shiffrin, R., \& Schneider, W. (1977). Controlled and automatic human information processing, II: Perceptual learning, automatic attending and a general theory. Psychological Review, 84, 127-190.

Skehan, P. (1998). A cognitive approach to language learning. Oxford: Oxford University Press.

Spada, N. (1997). Form-focused instruction and second language acquisition: A review of classroom and laboratory research. Language Teaching, 30, 7387. 
SPSS Inc. (1999). SPSS Statistical Software Package (Release 10.0J for Windows) [Computer Software]. Tokyo: SPSS Japan Inc.

Swain, M. (1985). Communicative competence: Some roles of comprehensible input and comprehensible output in its development. In S. Gass \& C. Madden (Eds.), Input in second language acquisition (pp. 235-252). Rowley, MA: Newbury House.

Swain, M. (1993). The output hypothesis: Just speaking and writing aren't enough. Canadian Modern Language Review, 50, 158-164.

Swain, M. (1995). Three functions of output in second language learning. In G. Cook, \& B. Seidlhofer (Eds.). Principle and practice in applied linguistics: Studies in honor of H. G. Widdowson (pp. 125-144). Oxford: Oxford University Press.

Tanaka, T. (1999). The effect of combination of comprehension and production practice in grammar instruction. JACET Bulletin, 30, 119-133.

Terrell, T. D. (1991). The role of grammar instruction in a communicative approach. Modern Language Journal, 75, 52-63.

VanPatten, B. (1987). On babies and bathwater: Input in foreign language learning. Modern Language Journal, 71, 156-164.

VanPatten, B., \& Cadierno, T. (1993). Explicit instruction and input processing. Studies in Second Language Acquisition, 15, 225-243.

White, L., Spada, N., Lightbown, P., \& Ranta, L. (1991). Input enhancement and L2 question formation. Applied Linguistics, 12, 416-432.

Yamaoka, T. (1992). Learning of linguistic rules in formal second language learning: A classification of the activity types from a psycholinguistic perspective. Studies in Linguistic Expression, 8, 1-13.

(Received December 25, 1999; revised November 6, 2000)

\section{Appendix 1}

\section{Listening Test for the General English Aural Proficiency Test}

1. What letter is $G$ after in the alphabet? Write the letter.

2. Tom, Bill, and Jack are all common names for what? Begin the word with $a$ " $B$ " and write the plural form.

3. What do you call a person who gives medical treatment to sick people? Begin with a "D."

4. If you mixed blue and yellow paint together, what color would you get? Write the word beginning with the letter " $G$."

5. How many ears does a dog have? Write the number.

6. We usually have three meals a day. What do you call the meal we have at noon? A five-letter word. 